\title{
Inheritance studies on grain iron and zinc concentration and agronomic traits in sorghum [Sorghum bicolor (L.) Moench]
}

\author{
Anil Gaddameedi ${ }^{\mathrm{a}, \mathrm{c}}$, Ravikiran K.T. ${ }^{\mathrm{b}}$, Riyazaddin Mohammed $^{\mathrm{a}, \mathrm{c}}$, Rahul M. Phuke ${ }^{\mathrm{d}}$, Sadaiah K. ${ }^{\mathrm{a}}$, \\ Kavi Kishor P.B. ${ }^{c}$, Ashok Kumar Are ${ }^{a, *}$ \\ a International Crops Research Institute for the Semi-Arid Tropics (ICRISAT), Patancheru, 502 324, Telangana, India \\ ${ }^{\mathrm{b}}$ Central Soil Salinity Research Institute, Karnal, Haryana, India \\ ${ }^{c}$ Department of Genetics, Osmania University, Hyderabad, 500 007, Telangana, India \\ d Indian Agricultural Research Institute, Regional Station, Indore, Madhya Pradesh, India
}

\section{A R T I C L E I N F O}

\section{Keywords:}

Sorghum

Biofortification

Gene action

Additive

Dominance

Grain Fe and Zn concentration

\begin{abstract}
A B S T R A C T
Sorghum is a major staple globally and biofortifying sorghum with increased grain iron and zinc complements ongoing efforts to combat micronutrient malnutrition. Limited information available on the nature and magnitude of gene effects for grain iron and zinc. So generation mean analysis was done using four crosses, ICSB $52 \times$ IS 13211, ICSB $52 \times$ SPV 1359, IS $20843 \times$ IS 2248 and IS $2248 \times$ IS 20843. Six generations, $\mathrm{P}_{1}, \mathrm{P}_{2}, \mathrm{~F}_{1}, \mathrm{~F}_{2}$, $B_{1}$ and $B_{2}$, were generated for each of these crosses which were evaluated during the postrainy season $2012-13$. The mean sum of squares due to generations were significant for days to flowering, plant height, grain yield/ plant, 100-grain weight, and grain Fe and Zn. Generation mean studies revealed the presence of both additive and dominant gene interactions in inheritance of agronomic traits. Duplicative epistasis was observed for days to flowering, plant height, grain yield/plant, 100-grain weight, and grain Zn with a predominance of dominant gene action in inheritance of these traits. Panicle length, panicle width, and grain Fe showed both additive and dominance gene effects, with higher magnitude of dominance. This information can be utilized in developing sorghum lines with high grain Fe and $\mathrm{Zn}$.
\end{abstract}

\section{Introduction}

Sorghum [Sorghum bicolor (L.) Moench], also called great millet, is the fifth most important cereal crop grown in the world and a major staple for millions of poor people living in the semi-arid regions. It is tolerant to drought and heat and is well adapted to semi-arid regions (Bavei et al., 2011). It is a nutri-rich grain cereal that finds uses as food, feed, fodder, fuel, and fiber. About $90 \%$ of the world's sorghum area lies in developing countries, mainly in Africa and Asia, with $7.8 \mathrm{~m}$ ha of it grown in India (FAO stat 2016). It is one of the cheapest sources of energy (63.4-72.5\% starch) and micronutrients, fulfilling the supply of essential mineral micronutrients to the poor in the semi-arid regions (Parthasarathy Rao et al., 2006; Ashok Kumar et al., 2011). Micronutrient malnutrition is a major global challenge which affects more than half the world's population, particularly adult females and preschool children in developing and underdeveloped countries (Nestel et al., 2006; Nahla et al., 2017). Mineral nutrients play a pivotal role in human growth and development. Deficiencies in iron (Fe) and zinc ( $\mathrm{Zn}$ ) are two of the most common and widespread micronutrient deficiencies
(Bailey et al., 2015; Phuke et al., 2017). This comes at a cost to society as the consequences include poor health, increased mortality, low work productivity, learning disabilities in children and poor economic development at the country level (Arzani and Ashraf, 2017). The main sources of iron and zinc are cereals, fruits and vegetables and meat. Plant foods contain almost all the mineral and organic nutrients considered essential for human nutrition (Arzani et al., 2007) but balancing them in the food basket is key. It is estimated that about $60-80 \%$ of the world's population is Fe deficient, and $>30 \%$ are $\mathrm{Zn}$ deficient (White and Broadley, 2006; Ma et al., 2008). All these have implications for the health and well-being of people and their economic development.

Efforts are underway to address micronutrient malnutrition or hidden hunger by various means. Biofortification is a sustainable option to combat micronutrient malnutrition and complements well the dietary diversification, food fortification, and supplementation that are currently employed to address micronutrient deficiency in human diets. Biofortification aims to combat malnutrition in communities in developing countries that do not mainly consume manufactured food products (Bouis and Welch, 2010). It involves increasing the density and

\footnotetext{
* Corresponding author.

E-mail address: a.ashokkumar@cgiar.org (A. Ashok Kumar).
} 
bioavailability of key essential nutrients, especially micronutrients in grains, by genetic means (White and Broadley, 2006; Zhao and Mcgrath, 2009; Arzani and Ashraf, 2017). Widespread interest is being shown in biofortification of sorghum by increasing mineral micronutrients (especially Fe and $\mathrm{Zn}$ ) in grains (Pfeiffer and McClafferty, 2007; Ashok Kumar et al., 2009). Preliminary studies indicated limited variability for grain Fe and $\mathrm{Zn}$ concentrations in sorghum hybrid parents, advanced breeding lines and germplasm accessions (Reddy et al., 2005). Upon studying larger sets of materials, large genetic variability for grain $\mathrm{Fe}\left(8-192 \mathrm{mg} \mathrm{kg}^{-1}\right)$ and $\mathrm{Zn} \mathrm{(14-91} \mathrm{mg} \mathrm{kg}^{-1}$ ) concentrations were reported in sorghum landrace accessions, hybrid parents and commercial hybrids (Ashok Kumar et al., 2009, 2012). The variability in the landraces can be effectively utilized in developing sorghum varieties, parents and hybrids with high grain $\mathrm{Fe}$ and $\mathrm{Zn}$ concentration.

Knowledge of trait inheritance is critical to exploit the large variability identified in sorghum (Ashok Kumar et al., 2013). Generation mean analysis provides information on the relative importance of average effects of the genes (additive effects), dominance deviations, and effects due to non-allelic genic interactions, in determining genotypic values of the individuals and, consequently, mean genotypic values of families and generations. Therefore, the present study was carried out to determine the inheritance pattern of $\mathrm{Fe}$ and $\mathrm{Zn}$ and agronomic traits using the generation mean analysis, trait heritability and type of gene action prevailing in sorghum.

\section{Materials and methods}

\subsection{Experimental material}

The material for this study comprised of six basic generations, i.e., $\mathrm{P}_{1}, \mathrm{P}_{2}, \mathrm{~F}_{1}, \mathrm{~F}_{2}, \mathrm{~B}_{1}$, and $\mathrm{B}_{2}$ developed involving five selected diverse parents during rainy and postrainy seasons of 2011 and rainy season of 2012. A total of four crosses, ICSB $52 \times$ IS13211, ICSB $52 \times$ SPV 1359 , IS20843 $\times$ IS2248, and IS2248 $\times$ IS20843 were made using five parents with diverse grain $\mathrm{Fe}$ and $\mathrm{Zn}$ concentrations. All the generations were evaluated during the postrainy season 2012-13 at ICRISAT, Patancheru located at an altitude of $545 \mathrm{~m}$ above mean sea level between latitude $17.53^{\circ} \mathrm{N}$ and longitude $78.27^{\circ} \mathrm{E}$. It took two seasons (2010 and 2011 postrainy seasons) to develop the $F_{1} s$ from the selected parents and make the $B_{1}$ and $B_{2}$ by crossing the $F_{1} s$ with both the parents. The $F_{1} s$ were advanced to $F_{2}$. Since development of generations involve crossing and backcrossing in four different cross combinations, the seeds were not sufficient to evaluate in multiples seasons/year. Therefore, only one season evaluation was done in postrainy season 2012-13.

To assess the generation, a trial was conducted in a randomized complete block design (RCBD), with two rows of parents and $F_{1}$, four rows of $B_{1}$ and $B_{2}$, and eight rows of $F_{2}$ generations. The length of each row was $2 \mathrm{~m}$ with spacing of $0.75 \mathrm{~m}$ between the rows. Plant to plant spacing of $10 \mathrm{~cm}$ was maintained in the rows, with a plant population of 20 per row. The seeds were sown at a depth of 2 inches using a seed planter. The field was irrigated during the trials in the postrainy season. The seedlings were thinned to one plant per hill at 7 days after seedling emergence (DAE). Hand weeding was carried out whenever necessary. The test material was protected from pests and diseases by spraying pesticides. Data were recorded on days to flowering, plant height, panicle length and width, grain yield, 100-seed weight and also grain $\mathrm{Fe}$ and $\mathrm{Zn}$ concentrations. The grain Fe and $\mathrm{Zn}$ analyses were carried out in the Charles Renard Analytical Laboratory (CRAL) at ICRISAT, Patancheru, India. The Fe and $\mathrm{Zn}$ concentrations in the samples were estimated using a prodigy high dispersion Inductively Coupled Plasma Optical Emission Spectrometer (ICP-OES) (Wheal et al., 2011). The soil sample were collected and analyzed for Fe and $\mathrm{Zn}\left(3.2 \mathrm{mg} \mathrm{kg}^{-1}\right.$ for Fe; and $1.4 \mathrm{mg} \mathrm{kg}^{-1}$ for $\mathrm{Zn}$ ). These Fe and $\mathrm{Zn}$ contents in the soil were in the sufficient range for normal plant requirements $\left(2.6-4.5 \mathrm{mg} \mathrm{kg}^{-1}\right.$ for Fe; $0.6-1.0 \mathrm{mg} \mathrm{kg}^{-1}$ for $\mathrm{Zn}$ ).
Table 1

Mean sum of squares of four different crosses of sorghum during the postrainy season, ICRISAT, Patancheru, 2012-13.

\begin{tabular}{|c|c|c|c|c|}
\hline Trait/cross & $\begin{array}{l}\text { ICSB } 52 \times \text { IS } \\
13211\end{array}$ & $\begin{array}{l}\text { ICSB } \\
52 \times \text { SPV } \\
1359\end{array}$ & $\begin{array}{l}\text { IS } 20843 \times \text { IS } \\
2248\end{array}$ & $\begin{array}{l}\text { IS } 2248 \times \text { IS } \\
20843\end{array}$ \\
\hline $\begin{array}{l}\text { Days to } \\
\text { flowering }\end{array}$ & $42.31^{* *}$ & $52.35^{* *}$ & $78.21^{* *}$ & $17.50^{* *}$ \\
\hline Plant height & $1755.49^{* *}$ & $3723.80^{* * *}$ & $226.35^{* *}$ & $128.73^{*}$ \\
\hline Panicle length & $4.27^{*}$ & 3.03 & $12.42 * *$ & $1.95^{* *}$ \\
\hline Panicle width & $1.95^{*}$ & 1.96 & 1.04 & $0.72^{* *}$ \\
\hline $\begin{array}{c}\text { Grain yield/ } \\
\text { plant }\end{array}$ & $112.59 * *$ & $434.07^{* *}$ & $1306.08^{* *}$ & $160.92^{* *}$ \\
\hline $\begin{array}{l}\text { 100-grain } \\
\text { weight }\end{array}$ & $0.40^{* *}$ & $0.11 *$ & $0.45^{* *}$ & $0.28^{* *}$ \\
\hline Grain $\mathrm{Fe}$ & $121.18^{* *}$ & $171.36^{* *}$ & $22.76^{* *}$ & 7.17 \\
\hline Grain Zn & $10.97 * *$ & $45.50 * *$ & $33.23^{* *}$ & $256.61 *$ \\
\hline
\end{tabular}

$*, * * \mathrm{P}$ value significant at $\leq 0.05$ and 0.01 , respectively.

\section{Statistical analysis}

The data obtained on agronomic and grain $\mathrm{Fe}$ and $\mathrm{Zn}$ traits were subjected to analysis of variance (ANOVA) using Windostat Indostat 8.5 software (2004). The significance of the test genotypes was assessed using the $\mathrm{F}$ probabilities at $\mathrm{P} \leq 0.05$. The generation mean analysis of the six populations $\left(\mathrm{P}_{1}, \mathrm{P}_{2}, \mathrm{~F}_{1}, \mathrm{~F}_{2}, \mathrm{~B}_{1}\right.$, and $\left.\mathrm{B}_{2}\right)$ and associated scaling tests (Mather, 1949; Cavalli, 1952) were performed based on the assumption that populations have non-homogeneous variances (Mather and Jinks, 1971). The adequacy of the additive (d) dominance (h) model was tested by the scaling test (Mather, 1949). The validity of this model for the scaling tests and non-allelic interactions was examined using Indostat 8.5 software.

\section{Results}

The analysis of mean sum of squares due to generations were significant $(\mathrm{P} \leq 0.05$ ) for days to flowering, plant height, grain yield/ plant, 100-grain weight and grain Fe and Zn concentrations in all the crosses (Table 1), which revealed the existence of genetic variability for these traits. The mean sum of squares due to generations were nonsignificant for panicle length and panicle width in the cross ICSB $52 \times$ SPV 1359, for panicle width in the cross IS $20843 \times$ IS 2248 and for grain Fe concentration in the cross IS $2248 \times$ IS 20843 . The data pertaining to the traits that exhibited non-significant deviation were not subjected to generation mean analysis.

\subsection{Mean performance of crosses}

There were significant differences between agronomic and morphological traits in all the crosses, with a few exceptions (Table 2). Genotype ICSB 52, IS 20843, and IS 2248 have high grain $\mathrm{Fe}$ $\left(40 \mathrm{mg} \mathrm{kg}^{-1}\right.$ ) concentration. $\mathrm{F}_{1}, \mathrm{~B}_{1}$ and $\mathrm{B}_{2}$ progenies of the crosses ICSB $52 \times$ IS 13211 and ICSB $52 \times$ SPV 1359 exhibited higher Fe concentration ( $>40 \mathrm{mg} \mathrm{kg}^{-1}$ ).

\subsection{Scaling test and estimation of genetic components of variation}

The agronomic and morphological traits showing significant probabilities were subjected to generation mean analysis to test the fitness of the additive-dominance model, and Hayman's six parameter model, to find the significant inter-allelic interactions. The generation means of different traits are explained below.

\subsubsection{Days to flowering}

All scales of the crosses ICSB $52 \times$ IS 13211 , ICSB $52 \times$ SPV 1359 , and IS $20843 \times$ IS 2248 and B, C, D scales of the cross IS $20843 \times$ IS 
Table 2

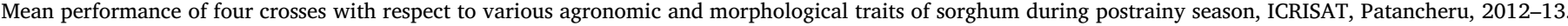

\begin{tabular}{|c|c|c|c|c|c|c|c|c|c|}
\hline Pedigree & Generation & $\begin{array}{l}\text { Days to } \\
\text { flowering }\end{array}$ & $\begin{array}{l}\text { Plant height } \\
(\mathrm{cm})\end{array}$ & $\begin{array}{l}\text { Panicle } \\
\text { length }(\mathrm{cm})\end{array}$ & $\begin{array}{l}\text { Panicle } \\
\text { width }(\mathrm{cm})\end{array}$ & $\begin{array}{l}\text { Grain yield/ } \\
\text { plant (g) }\end{array}$ & $\begin{array}{l}\text { 100-grain } \\
\text { weight }(g)\end{array}$ & $\begin{array}{l}\text { Grain Fe (mg } \\
\left.\mathrm{kg}-^{1}\right)\end{array}$ & $\begin{array}{l}\text { Grain Zn (mg } \\
\mathrm{kg}^{-1} \text { ) }\end{array}$ \\
\hline \multicolumn{10}{|l|}{ ICSB $52 \times$ IS 13211} \\
\hline ICSB 52 & $\mathrm{P}_{1}$ & 59.40 & 145.80 & 25.60 & 9.40 & 50.94 & 3.80 & 40.64 & 26.90 \\
\hline IS 13211 & $\mathrm{P}_{2}$ & 57.60 & 196.80 & 24.90 & 10.10 & 36.86 & 2.70 & 29.05 & 31.31 \\
\hline ICSB $52 \times$ IS 13211 & $\mathrm{~F}_{1}$ & 56.50 & 202.40 & 24.10 & 9.40 & 31.19 & 3.30 & 45.60 & 28.00 \\
\hline ICSB $52 \times$ IS 13211 & $\mathrm{~F}_{2}$ & 56.20 & 199.90 & 24.80 & 10.10 & 42.60 & 3.60 & 39.70 & 25.60 \\
\hline $\begin{array}{l}(\mathrm{ICSB} 52 \times \text { IS } \\
13211) \times \text { ICSB } 52\end{array}$ & $\mathrm{~B}_{1}$ & 55.80 & 207.10 & 27.20 & 11.60 & 39.00 & 3.40 & 46.90 & 27.60 \\
\hline $\begin{array}{l}(\text { ICSB } 52 \times \text { IS 13211) } \times \text { IS } \\
\quad 13211\end{array}$ & $\mathrm{~B}_{2}$ & 65.70 & 220.00 & 26.60 & 10.30 & 33.40 & 3.20 & 42.00 & 28.10 \\
\hline Mean & & 58.36 & 205.24 & 25.52 & 10.30 & 36.61 & 3.24 & 40.65 & 28.12 \\
\hline CV\% & & 1.87 & 1.89 & 4.01 & 6.82 & 9.97 & 6.73 & 2.61 & 6.73 \\
\hline $\mathrm{SE} \pm$ & & 0.60 & 2.10 & 0.50 & 0.40 & 2.00 & 0.10 & 0.60 & 1.00 \\
\hline $\mathrm{Vr}$ & & $13.69 * *$ & $580.65^{* *}$ & $1.07^{*}$ & $0.488^{*}$ & $32.21 * *$ & $0.115^{* *}$ & $40.01^{* *}$ & 2.40 \\
\hline $\mathrm{CD}(\mathrm{P} \leq 0.05)$ & & 2.00 & 6.60 & 1.80 & 1.20 & 7.20 & 0.40 & 1.90 & NS \\
\hline \multicolumn{10}{|l|}{ ICSB $52 \times$ SPV 1359} \\
\hline ICSB 52 & $\mathrm{P}_{1}$ & 64.00 & 134.90 & 23.40 & 10.80 & 60.20 & 4.40 & 40.70 & 28.70 \\
\hline IS 13211 & $\mathrm{P}_{2}$ & 55.00 & 163.90 & 23.00 & 10.90 & 75.50 & 4.10 & 28.10 & 21.00 \\
\hline ICSB $52 \times$ SPV 1359 & $\mathrm{~F}_{1}$ & 62.50 & 207.80 & 24.70 & 10.50 & 48.20 & 3.90 & 49.50 & 30.70 \\
\hline ICSB $52 \times$ SPV 1359 & $\mathrm{~F}_{2}$ & 59.50 & 208.80 & 22.50 & 10.10 & 40.50 & 4.00 & 39.70 & 28.90 \\
\hline $\begin{array}{l}(\mathrm{ICSB} 52 \times \text { SPV } \\
1359) \times \text { ICSB } 52\end{array}$ & $\mathrm{~B}_{1}$ & 66.90 & 204.80 & 25.10 & 11.90 & 60.70 & 4.30 & 47.10 & 30.50 \\
\hline $\begin{array}{l}(\mathrm{ICSB} 52 \times \mathrm{SPV} \\
1359) \times \mathrm{SPV} 1359\end{array}$ & $\mathrm{~B}_{2}$ & 64.00 & 230.20 & 24.10 & 12.10 & 60.30 & 4.30 & 38.10 & 32.10 \\
\hline Mean & & 61.58 & 203.10 & 23.88 & 11.10 & 57.04 & 4.12 & 40.50 & 28.64 \\
\hline CV\% & & 2.65 & 3.26 & 4.77 & 8.45 & 5.07 & 3.45 & 6.73 & 4.92 \\
\hline $\mathrm{SE} \pm$ & & 0.90 & 3.60 & 0.60 & 0.50 & 1.60 & - & 1.50 & 0.80 \\
\hline $\mathrm{Vr}$ & & $16.54 * *$ & $1228.15^{* *}$ & 0.57 & 0.36 & $141.84 * *$ & $0.03^{*}$ & $54.62 * *$ & $14.5^{* * *}$ \\
\hline $\mathrm{CD}(\mathrm{P} \leq 0.05)$ & & 2.90 & 11.40 & NS & NS & 5.30 & 0.26 & 4.90 & 2.50 \\
\hline \multicolumn{10}{|l|}{ IS $20843 \times$ IS 2248} \\
\hline IS 20843 & $\mathrm{P}_{1}$ & 65.20 & 226.20 & 19.20 & 7.90 & 57.40 & 3.80 & 40.60 & 37.80 \\
\hline IS 2248 & $\mathrm{P}_{2}$ & 54.50 & 218.20 & 19.80 & 8.10 & 27.50 & 2.80 & 41.80 & 42.00 \\
\hline IS $20843 \times$ IS 2248 & $\mathrm{~F}_{1}$ & 53.50 & 218.30 & 23.40 & 9.40 & 56.00 & 3.70 & 38.40 & 33.20 \\
\hline IS $20843 \times$ IS 2248 & $\mathrm{~F}_{2}$ & 53.40 & 200.10 & 18.80 & 8.30 & 29.50 & 3.20 & 43.70 & 34.00 \\
\hline $\begin{array}{l}\text { (IS, } 20843 \times \text { IS } 2248) \times \text { IS } \\
20843\end{array}$ & $\mathrm{~B}_{1}$ & 62.80 & 217.80 & 17.30 & 7.80 & 84.00 & 3.70 & 43.90 & 36.00 \\
\hline $\begin{array}{l}\text { (IS, } 20843 \times \text { IS } 2248) \times \text { IS } \\
\quad 2248\end{array}$ & $\mathrm{~B}_{2}$ & 56.50 & 218.90 & 20.10 & 8.30 & 47.70 & 3.50 & 46.20 & 39.30 \\
\hline Mean & & 56.14 & 214.66 & 19.88 & 8.38 & 48.94 & 3.38 & 42.80 & 36.90 \\
\hline CV\% & & 1.01 & 2.57 & 5.09 & 8.16 & 1.61 & 4.89 & 3.66 & 4.48 \\
\hline $\mathrm{SE} \pm$ & & 0.60 & 2.10 & 0.50 & 0.40 & 2.00 & 0.10 & 0.60 & 1.00 \\
\hline $\mathrm{Vr}$ & & $25.95^{* *}$ & $65.17 * *$ & $3.8^{* *}$ & 0.19 & $435.14^{* *}$ & $0.14^{* *}$ & $6.78^{* *}$ & $10.15^{* *}$ \\
\hline $\mathrm{CD}(\mathrm{P} \leq 0.05)$ & & 2.00 & 6.60 & 1.80 & NS & 7.20 & 0.40 & 1.90 & NS \\
\hline \multicolumn{10}{|l|}{ IS $2248 \times$ IS 20843} \\
\hline IS 2248 & $\mathrm{P}_{1}$ & 56.30 & 204.20 & 22.00 & 10.10 & 24.10 & 3.00 & 43.60 & 38.60 \\
\hline IS 20843 & $\mathrm{P}_{2}$ & 58.00 & 214.80 & 21.30 & 9.80 & 40.60 & 3.10 & 42.60 & 34.30 \\
\hline IS $2248 \times$ IS 20843 & $\mathrm{~F}_{1}$ & 52.00 & 220.60 & 20.80 & 10.30 & 37.30 & 3.10 & 40.50 & 34.60 \\
\hline IS $2248 \times$ IS 20843 & $\mathrm{~F}_{2}$ & 53.60 & 216.10 & 21.30 & 9.00 & 32.50 & 3.30 & 43.50 & 36.70 \\
\hline $\begin{array}{l}\text { (IS } 2248 \times \text { IS, 20843) } \times \text { IS } \\
\quad 2248\end{array}$ & $\mathrm{~B}_{1}$ & 54.00 & 222.70 & 21.40 & 9.60 & 34.00 & 3.20 & 44.90 & 41.40 \\
\hline $\begin{array}{l}\text { (IS } 2248 \times \text { IS, 20843) } \times \text { IS } \\
20843\end{array}$ & $\mathrm{~B}_{2}$ & 57.60 & 218.20 & 23.10 & 10.30 & 45.40 & 3.80 & 41.70 & 33.83 \\
\hline Mean & & 55.04 & 218.48 & 21.58 & 9.80 & 37.96 & 3.30 & 42.64 & 36.17 \\
\hline CV\% & & 2.47 & 2.74 & 3.61 & 2.60 & 7.22 & 2.89 & 4.22 & 6.64 \\
\hline $\mathrm{SE} \pm$ & & 0.90 & 3.60 & 0.60 & 0.50 & 1.60 & - & 1.50 & 0.80 \\
\hline $\mathrm{Vr}$ & & $5.21 * *$ & $31.16^{*}$ & 0.44 & $0.21 * *$ & $51.42 * *$ & $0.08^{* *}$ & 1.29 & $6.89^{*}$ \\
\hline $\mathrm{CD}(\mathrm{P} \leq 0.05)$ & & 2.90 & 11.40 & NS & - & 5.30 & 0.26 & NS & 2.50 \\
\hline
\end{tabular}

$*, * * \mathrm{P}$ value significant at $\leq 0.05$ and 0.01 , respectively.

2248 were significant for days to flowering, indicating the inadequacy of the additive-dominance model in explaining the inheritance of this trait (Tables 3 and 4). Partitioning the generation means showed significant means $(\mathrm{m})$ and additive $(\mathrm{d})$, dominance $(\mathrm{h})$, additive $\times$ additive (i), and dominance $\times$ dominance (1) components. The dominance and dominance $\times$ dominance components were in opposite directions indicating the presence of duplicative epistasis in inheritance of this trait. The dominance degree was $>1.00$ for ICSB $52 \times$ IS 13211 , ICSB $52 \times$ SPV 1359, and IS $20843 \times$ IS 2248 (Table 5) with slightly high dominance variance indicating the predominance of dominant gene action in the inheritance of this trait.

\subsubsection{Plant height}

Crosses ICSB $52 \times$ IS 13211 and ICSB $52 \times$ SPV 1359 exhibited significance for all scales, whereas A and C scales for the cross IS $20843 \times$ IS 2248 and A scale for the cross IS $2248 \times$ IS 20843 were significant, indicating the presence of non-allelic interactions (Tables 3 and 4). Partitioning of generation means showed significant means (m) and dominance $(\mathrm{h})$, additive $\times$ additive (i) and dominance $\times$ dominance (1) components. The dominance and dominance $\times$ dominance 
Table 3

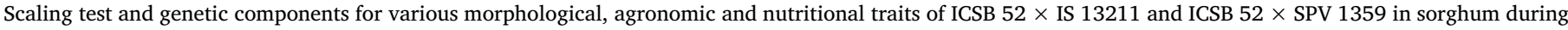
postrainy season, ICRISAT, Patancheru, 2012-13.

\begin{tabular}{|c|c|c|c|c|c|c|c|}
\hline & Days to flowering & Plant height $(\mathrm{cm})$ & Panicle length $(\mathrm{cm})$ & Panicle width $(\mathrm{cm})$ & Grain yield/plant (g) & 100-grain weight $(\mathrm{g})$ & Grain $\mathrm{Fe}\left(\mathrm{mg} \mathrm{kg}^{-1}\right)$ \\
\hline \multicolumn{8}{|c|}{ ICSB $52 \times$ IS 13211} \\
\hline \multicolumn{8}{|c|}{ Scaling test } \\
\hline A & $-3.87 \pm 0.89 * *$ & $65.76 \pm 5.88^{* *}$ & $4.36 \pm 2.17^{*}$ & $4.29 \pm 1.38^{* *}$ & $-12.55 \pm 10.61$ & $-0.17 \pm 0.31$ & $7.46 \pm 2.70^{* *}$ \\
\hline B & $17.13 \pm 1.11^{* *}$ & $25.19 \pm 7.33^{* *}$ & $4.23 \pm 1.58^{* *}$ & $1.3 \pm 1.09$ & $-6.96 \pm 6.44$ & $0.37 \pm 0.36$ & $8.90 \pm 3.66^{*}$ \\
\hline $\mathrm{C}$ & $-5.35 \pm 1.15^{* *}$ & $52.30 \pm 7.85^{* *}$ & $0.09 \pm 1.88$ & $2.4 \pm 1.20^{*}$ & $8.32 \pm 7.33$ & $1.27 \pm 0.38^{* *}$ & $-2.65 \pm 3.38$ \\
\hline $\mathrm{D}$ & $-9.30 \pm 0.67^{* *}$ & $-19.32 \pm 4.53^{* *}$ & $-4.25 \pm 1.37 * *$ & $-1.62 \pm 0.89$ & $13.92 \pm 6.66^{*}$ & $0.53 \pm 2.22^{*}$ & $-9.51 \pm 2.15^{* *}$ \\
\hline \multicolumn{8}{|c|}{ Genetic components } \\
\hline $\mathrm{m}$ & $56.22 \pm 0.15^{* *}$ & $199.81 \pm 1.07^{* *}$ & $24.86 \pm 0.31^{* *}$ & $10.11 \pm 0.19 * *$ & $42.58 \pm 1.46^{* *}$ & $3.64 \pm 0.05^{* *}$ & $39.81 \pm 0.48^{* *}$ \\
\hline $\mathrm{d}$ & $-9.75 \pm 0.60^{* *}$ & $-4.79 \pm 3.98$ & $0.48 \pm 1.22$ & $1.22 \pm 0.80$ & $4.27 \pm 5.97$ & $0.24 \pm 0.19$ & $5.32 \pm 1.92^{*}$ \\
\hline $\mathrm{h}$ & $16.65 \pm 1.44^{* *}$ & $69.01 \pm 9.64 * *$ & $7.49 \pm 0.2 .83^{* *}$ & $2.74 \pm 1.84$ & $-34.70 \pm 13.35^{* *}$ & $-1.0 \pm 0.47^{*}$ & $30.28 \pm 4.53^{* *}$ \\
\hline $\mathrm{i}$ & $18.61 \pm 1.35^{* *}$ & $38.65 \pm 9.07 * *$ & $8.50 \pm 2.74 * *$ & $3.25 \pm 0.07^{* *}$ & $-27.85 \pm 13.32^{*}$ & $-1.07 \pm 0.44^{*}$ & $19.02 \pm 4.31^{* *}$ \\
\hline $\mathrm{j}$ & $-10.50 \pm 0.64$ & $20.28 \pm 4.19$ & $0.06 \pm 1.28$ & $1.46 \pm 0.84$ & $-2.79 \pm 6.0$ & $-0.27 \pm 0.22$ & $-0.72 \pm 2.17$ \\
\hline 1 & $-31.86 \pm 2.68^{* *}$ & $-129.61 \pm 17.78^{* *}$ & $-17.11 \pm 5.23^{* *}$ & $-8.93 \pm 1.78$ & $47.37 \pm 25$ & $0.87 \pm 0.87$ & $-35.38 \pm 8.4^{* *}$ \\
\hline
\end{tabular}

ICSB 52 X SPV 1359

\begin{tabular}{|c|c|c|c|c|c|c|}
\hline & Days to flowering & Plant height $(\mathrm{cm})$ & Grain yield/plant $(\mathrm{g})$ & 100-grain weight (g) & Grain $\mathrm{Fe}\left(\mathrm{mg} \mathrm{kg}^{-1}\right)$ & Grain $\mathrm{Zn}\left(\mathrm{mg} \mathrm{kg}^{-1}\right)$ \\
\hline \multicolumn{7}{|c|}{ Scaling test } \\
\hline A & $6.78 \pm 1.63^{* *}$ & $62.21 \pm 9.09^{* *}$ & $7.13 \pm 4.17$ & $0.16 \pm 0.30$ & $3.13 \pm 2.28$ & $0.79 \pm 2.28$ \\
\hline B & $10.90 \pm 1.97^{* *}$ & $86.88 \pm 8.22^{* *}$ & $-4.46 \pm 5.32$ & $0.61 \pm 0.29 *$ & $-72.43 \pm 4.82$ & $1.69 \pm 6.26$ \\
\hline $\mathrm{C}$ & $-4.15 \pm 1.72^{*}$ & $117.19 \pm 8.64^{* *}$ & $-74.44 \pm 6.37^{* *}$ & $-0.11 \pm 0.37$ & $-8.97 \pm 3.61 *$ & $-5.81 \pm 4.63$ \\
\hline $\mathrm{D}$ & $-10.92 \pm 1.39 * *$ & $-15.95 \pm 6.71 *$ & $-38.55 \pm 2.96^{* *}$ & $-0.44 \pm 0.19^{*}$ & $-4.83 \pm 2.82$ & $-4.14 \pm 3.49$ \\
\hline \multicolumn{7}{|c|}{ Genetic components } \\
\hline $\mathrm{m}$ & $59.96 \pm 0.34^{* *}$ & $208.78 \pm 1.71^{* *}$ & $40.10 \pm 0.74^{* *}$ & $4.08 \pm 0.05^{* *}$ & $39.77 \pm 0.68^{* *}$ & $39.77 \pm 0.68^{* *}$ \\
\hline $\mathrm{d}$ & $2.48 \pm 1.20^{*}$ & $-26.84 \pm 5.77 * *$ & $-1.82 \pm 2.56$ & $-0.06 \pm 0.17$ & $9.04 \pm 2.47^{* *}$ & $9.04 \pm 2.47 * *$ \\
\hline $\mathrm{h}$ & $24.76 \pm 2.82^{* *}$ & $92.02 \pm 13.68^{* *}$ & $58.67 \pm 6.55^{* *}$ & $0.63 \pm 0.42$ & $19.91 \pm 5.79^{* *}$ & $24.94 \pm 5.77^{* *}$ \\
\hline $\mathrm{i}$ & $21.85 \pm 2.78^{* *}$ & $31.90 \pm 13.43$ & $77.11 \pm 5.92^{* * *}$ & $0.89 \pm 0.39^{*}$ & $9.67 \pm 5.64$ & $9.67 \pm 5.64$ \\
\hline $\mathrm{j}$ & $-2.06 \pm 1.25$ & $-12.33 \pm 5.91$ & $-5.79 \pm 2.90$ & $-0.22 \pm 0.18$ & $9.36 \pm 2.62$ & $2.78 \pm 2.61$ \\
\hline 1 & $-39.54 \pm 5.11^{* *}$ & $-180.99 \pm 24.65^{* *}$ & $-79.78 \pm 12.06^{* *}$ & $-1.66 \pm 0.77^{*}$ & $-13.40 \pm 10.57$ & $-10.37 \pm 10.52$ \\
\hline
\end{tabular}

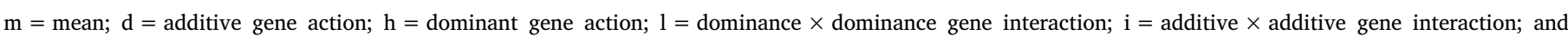
$\mathrm{j}=$ additive $\times$ dominant gene interaction.

$*$, **t-test significant at $\mathrm{P} \leq 0.05$ and 0.01 , respectively.

components were in the opposite direction indicating the presence of duplicative epistasis in inheritance of this trait. Crosses ICSB $52 \times$ IS 13211 and IS $2248 \times$ IS 20843 exhibited high additive variance and dominance degree of $>1.00$, indicating both the additive and dominance genes were involved in the inheritance of this trait (Table 5).

\subsubsection{Panicle length}

The $\mathrm{F}$ value for panicle length in the crosses ICSB $52 \times$ SPV 1359 and IS $2248 \times$ IS 20843 was not significant. Hence, these crosses were not subjected to generation mean analysis. The significance of A, B, D scales for ICSB $52 \times$ IS 13211 and A and C scales for IS $20843 \times$ IS 2248 indicated the presence of non-allelic interactions in the inheritance of this trait (Tables 3 and 4). Partitioning into genetic components revealed significant means and dominance, additive $\times$ additive and dominance $\times$ dominance components for ICSB $52 \times$ IS 13211 and additive, dominance $\times$ dominance interactions for IS $20843 \times$ IS 2248 . The dominance variance for ICSB $52 \times$ IS 13211 and IS $20843 \times$ IS 2248 was greater than the additive variance (Table 5 ) and dominance degree of $>1.00$ was recorded in ICSB $52 \times$ IS 13211 .

\subsubsection{Panicle width}

Panicle width for the crosses ICSB $52 \times$ SPV 1359 and IS $20843 \times$ IS 2248 showed non-significant F value; so these crosses were not involved in generation mean studies. Scaling test of remaining crosses exhibited significant A and C scales for ICSB $52 \times$ IS 13211 and $\mathrm{C}$ and D scales for IS $2248 \times$ IS 20843 , indicating inadequacy of the additive-dominance model, and the presence of epistatic interactions in inheritance of this trait (Tables 3 and 4). Partitioning of generation means showed significant mean. The genetic component revealed significant mean and additive $\times$ additive components for ICSB $52 \times$ IS 13211 and dominance, additive $\times$ additive components for IS
$2248 \times$ IS 20843, indicating both dominance and additive interactions were involved in the inheritance of this trait. The variance due to the dominant genes was higher than the additive variance for the crosses ICSB $52 \times$ IS 13211 and IS $2248 \times$ IS 20843 , indicating the predominance of dominant gene action in the inheritance of this trait (Table 5).

\subsubsection{Grain yield/plant}

Scale D for ICSB $52 \times$ IS 13211; C and D for ICSB $52 \times$ SPV 1359; and all the four scales for IS $20843 \times$ IS 2248 and IS $2248 \times$ IS 20843 were significant, indicating the presence of non-allelic interactions in the inheritance of this trait (Tables 3 and 4). To identify the type of interaction, generation means were partitioned into six components. Crosses ICSB $52 \times$ IS 13211 and IS $2248 \times$ IS 20843 showed significant dominance and additive $\times$ additive interactions, whereas crosses ICSB $52 \times$ SPV 1359 and IS $20843 \times$ IS 2248 exhibited significant dominance, additive $\times$ additive, and dominance $\times$ dominance interactions. The dominance and dominance $\times$ dominance interactions were in opposite directions, which is a sign of the involvement of duplicate epistatic interactions in the inheritance of this trait. The dominance degree for the cross IS $20843 \times$ IS 2248 was $>1.00$ (Table 5). All the four crosses exhibited high phenotypic variance. Crosses ICSB $52 \times$ IS 13211 and IS $20843 \times$ IS 2248 exhibited higher dominance variance than additive variance.

\subsubsection{Hundred grain weight}

The scaling test on all the four crosses exhibited significant scales indicating the inadequacy of the additive-dominance model in explaining the inheritance of this trait (Tables 3 and 4). Hence, the generation means were partitioned into six genetic components. The dominance and additive $\times$ additive interactions were significant for 
Table 4

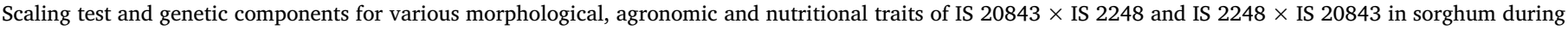
postrainy season, ICRISAT, Patancheru, 2012-13.

\begin{tabular}{|c|c|c|c|c|c|c|c|}
\hline & Days to flowering & Plant height $(\mathrm{cm})$ & Panicle width $(\mathrm{cm})$ & Grain yield/plant (g) & 100-grain weight $(\mathrm{g})$ & Grain Fe $\left(\mathrm{mg} \mathrm{kg}^{-1}\right)$ & Grain $\mathrm{Zn}\left(\mathrm{mg} \mathrm{kg}^{-1}\right)$ \\
\hline \multicolumn{8}{|c|}{ IS $20843 \times$ IS 2248} \\
\hline \multicolumn{8}{|c|}{ Scaling test } \\
\hline A & $6.96 \pm 0.37^{* *}$ & $-7.31 \pm 5.16$ & $-1.82 \pm 1.12$ & $54.67 \pm 3.55^{* *}$ & $-0.06 \pm 0.26$ & $9.03 \pm 2.70^{* *}$ & $0.92 \pm 2.66$ \\
\hline B & $5.07 \pm 0.48^{* *}$ & $-0.003 \pm 5.46$ & $-0.81 \pm 0.98$ & $11.86 \pm 1.72^{* *}$ & $0.45 \pm 0.29$ & $12.61 \pm 3.48^{* *}$ & $3.30 \pm 2.05$ \\
\hline $\mathrm{C}$ & $-12.45 . \pm 0.41^{* *}$ & $-77.38 \pm 5.43^{* *}$ & $-1.05 \pm 0.98$ & $-77.87 \pm 2.89^{* *}$ & $-1.48 \pm 0.25^{* *}$ & $17.99 \pm 3.28^{* *}$ & $-10.59 \pm 2.57^{* *}$ \\
\hline $\mathrm{D}$ & $-12 \pm 0.31^{* *}$ & $-35.03 \pm 3.68^{* *}$ & $0.79 \pm 0.78$ & $-72.20 \pm 1.93^{* *}$ & $-0.93 \pm 0.19^{* *}$ & $-1.82 \pm 2.14$ & $-7.41 \pm 1.58^{* *}$ \\
\hline \multicolumn{8}{|c|}{ Genetic components } \\
\hline $\mathrm{m}$ & $53.66 \pm 0.6^{* *}$ & $200.69 \pm 0.63^{* *}$ & $8.48 \pm 0.18^{* *}$ & $29.77 \pm 0.41 * *$ & $3.18 \pm 0.04 * *$ & $44.17 \pm 0.47^{* *}$ & $33.96 \pm 0.35^{* *}$ \\
\hline d & $6.28 \pm 0.27^{* *}$ & $0.57 \pm 3.32$ & $-0.57 \pm 0.69$ & $36.36 \pm 1.74^{* *}$ & $0.25 \pm 0.17$ & $-2.20 \pm 1.92$ & $-3.36 \pm 1.41^{*}$ \\
\hline $\mathrm{h}$ & $18.10 \pm 0.64^{* *}$ & $66.45 \pm 7.69 * *$ & $-0.10 \pm 1.60$ & $157.95 \pm 4.05^{* *}$ & $2.25 \pm 0.40^{* *}$ & $0.93 \pm 4.49$ & $7.91 \pm 3.35^{*}$ \\
\hline $\mathrm{i}$ & $24.48 \pm 0.62^{* *}$ & $70.07 \pm 7.37^{* *}$ & $-1.58 \pm 1.56$ & $144.41 \pm 3.9^{* *}$ & $1.86 \pm 0.39^{* *}$ & $3.65 \pm 4.29$ & $14.82 \pm 4.66^{* *}$ \\
\hline $\mathrm{j}$ & $0.94 \pm 0.29$ & $-3.65 \pm 3.51$ & $-0.50 \pm 0.72$ & $21.40 \pm 1.83$ & $-0.25 \pm 0.19$ & $-1.78 \pm 2.05$ & $-1.19 \pm 1.58$ \\
\hline 1 & $-36.52 \pm 1.18^{* *}$ & $-62.75 \pm 14.35^{* *}$ & $4.22 \pm 2.94$ & $-210.94 \pm 7.52^{* *}$ & $-2.25 \pm 0.75^{* *}$ & $-25.31 \pm 8.37^{* *}$ & $-19.05 \pm 6.22^{* *}$ \\
\hline
\end{tabular}

IS $2248 \times$ IS 20843

\begin{tabular}{|c|c|c|c|c|c|c|}
\hline & Days to flowering & Plant height $(\mathrm{cm})$ & Panicle width $(\mathrm{cm})$ & Grain yield/plant $(\mathrm{g})$ & 100-grain weight $(\mathrm{g})$ & Grain $\mathrm{Zn}\left(\mathrm{mg} \mathrm{kg}^{-1}\right)$ \\
\hline \multicolumn{7}{|c|}{ Scaling test } \\
\hline $\mathrm{A}$ & $0.57 \pm 0.77$ & $19.49 \pm 5.68^{* *}$ & $-0.87 \pm 0.88$ & $8.52 \pm 3.61^{*}$ & $0.29 \pm 0.24$ & $9.16 \pm 3.56^{*}$ \\
\hline B & $4.91 \pm 0.81^{* *}$ & $0.57 \pm 5.17$ & $0.38 \pm 0.691$ & $13.96 \pm 4.20^{* *}$ & $1.46 \pm 0.23^{* *}$ & $-0.57 \pm 3.64$ \\
\hline $\mathrm{C}$ & $-2.55 \pm 0.81^{* *}$ & $9.62 \pm 6.44$ & $-4.20 \pm 0.91 * *$ & $-10.17 \pm 4.02^{*}$ & $0.94 \pm 0.28^{* *}$ & $1.36 \pm 3.94$ \\
\hline $\mathrm{D}$ & $-4.02 \pm 0.59^{* *}$ & $-5.22 \pm 3.67$ & $-1.85 \pm 0.51^{* *}$ & $-16.33 \pm 2.96^{* *}$ & $-0.41 \pm 0.15^{*}$ & $-3.61 \pm 2.54$ \\
\hline \multicolumn{7}{|c|}{ Genetic components } \\
\hline $\mathrm{m}$ & $53.66 \pm 0.14^{* *}$ & $217.30 \pm 0.89^{* *}$ & $9.07 \pm 0.12^{* *}$ & $32.18 \pm 0.75^{* *}$ & $3.33 \pm 0.03^{* *}$ & $35.92 \pm 0.59^{* *}$ \\
\hline $\mathrm{d}$ & $-3.10 \pm 0.51^{* *}$ & $3.84 \pm 3.20$ & $-0.52 \pm 0.45$ & $-11.02 \pm 2.55^{* *}$ & $-0.64 \pm 0.13$ & $6.93 \pm 2.24 * *$ \\
\hline $\mathrm{h}$ & $2.91 \pm 1.22^{*}$ & $21.63 \pm 7.81^{* *}$ & $4.03 \pm 1.10^{* *}$ & $37.82 \pm 6.08^{* *}$ & $0.87 \pm 0.33^{*}$ & $5.47 \pm 5.32$ \\
\hline $\mathrm{i}$ & $8.04 \pm 1.19^{* *}$ & $10.44 \pm 7.34$ & $-3.71 \pm 1.03^{* *}$ & $32.66 \pm 5.93^{* *}$ & $0.82 \pm 0.31^{*}$ & $7.23 \pm 5.09$ \\
\hline $\mathrm{j}$ & $-2.16 \pm 0.54$ & $9.46 \pm 3.48$ & $-0.62 \pm 0.51$ & $-2.71 \pm 2.65$ & $-0.58 \pm 0.15$ & $4.86 \pm 2.34$ \\
\hline 1 & $-13.54 \pm 2.21^{* *}$ & $-30.51 \pm 14.34 *$ & $-3.22 \pm 2.04$ & $-55.14 \pm 10.99^{* *}$ & $-2.58 \pm 0.62^{* *}$ & $-15.82 \pm 9.81$ \\
\hline
\end{tabular}

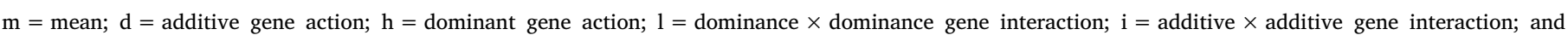
$\mathrm{j}=$ additive $\times$ dominant gene interaction.

$*$, **t-test significant at $\mathrm{P}<0.05$ and 0.01 , respectively.

ICSB $52 \times$ IS 13211, whereas additive $\times$ additive and dominance $\times$ dominance interactions were seen governing the trait concerned.

The additive component was found non-significant whereas the dominance component was significant in all crosses, except ICSB $52 \times$ SPV 1359. Among the interactions, additive $\times$ additive (i) component was significant in a positive direction in all the crosses except ICSB $52 \times$ SPV 1359. Cross IS $20843 \times$ IS 2248 exhibited significant dominance, additive $\times$ additive and dominance $\times$ dominance interactions and additive, dominance, additive $\times$ additive, and dominance $\times$ dominance interactions for IS $2248 \times$ IS 20843 , and the dominance and dominance $\times$ dominance interactions were in opposite directions indicating the duplicate epistasis in the inheritance of this trait.

\subsubsection{Grain Fe concentration}

The scales A, B, and D for ICSB $52 \times$ IS 13211; C for ICSB $52 \times$ SPV 1359; and A, B, and C for IS $20843 \times$ IS 2248 were significant, indicating the presence of non-allelic interactions in the inheritance of this trait. The F value for IS $2248 \times$ IS 20843 was not significant for this trait; hence it was not involved in generation mean studies of this trait. Partitioning of the genetic components revealed the significant means for all the crosses. Additive, dominance, additive $\times$ additive and dominance $\times$ dominance components were significant for the cross ICSB $52 \times$ IS 13211 and additive and dominance for ICSB $52 \times$ SPV 1359; and dominance $\times$ dominance for IS $20843 \times$ IS 2248 . Phenotypic variance was high in all the crosses (Table 5). The dominance variance was higher than the additive variance in all the crosses, with dominance degree $>1.00$ for ICSB $52 \times$ IS 13211 and ICSB $52 \times$ SPV 1359

\subsubsection{Grain $\mathrm{Zn}$ concentration}

Cross ICSB $52 \times$ IS 13211 had non-significant $F$ value for this trait and hence this cross was not involved in the generation mean studies. Cross ICSB $52 \times$ SPV 1359 exhibited non-significant scaling test indicating the additive-dominance model was sufficient to explain the inheritance of this trait (Table 3). Crosses IS $20843 \times$ IS 2248 and IS $2248 \times$ IS 20843 showed at least one significant scale indicating the presence of epistatic inheritance for this trait (Table 4). Partitioning of genetic components revealed significant means for these crosses. Cross ICSB $52 \times$ SPV 1359 showed significant additive and dominance genetic components whereas cross IS $20843 \times$ IS 2248 exhibited significant additive, dominance, additive $\times$ additive, and dominance $\times$ dominance components. The dominance and dominance $\times$ dominance components were in opposite directions for IS $20843 \times$ IS 2248, indicating duplicate epistasis in the inheritance of this trait. Phenotypic variance was high for all the crosses (Table 5). The dominance variance is higher than the additive variance for crosses ICSB $52 \times$ SPV 1359 and IS $2248 \times$ IS 20843 .

Only one scaling test, i.e., scale C was significant in crosses ICSB $52 \times$ IS 13211 and IS $20843 \times$ IS 2248; and scale-A was significant in cross IS $2248 \times$ IS 20843 , indicating the inadequacy of the additivedominance model in explaining the inheritance of grain zinc concentration. However, none of the scaling tests was found significant for grain zinc concentration in cross ICSB $52 \times$ SPV 1359, for which there were significant differences among generations indicating the adequacy of the additive-dominance model in explaining the inheritance of this character and the absence of epistasis.

Estimates of the additive component were significant in a positive direction in the crosses ICSB $52 \times$ SPV 1359 and IS $2248 \times$ IS 20843 and negatively significant in the cross IS $20843 \times$ IS 2248 and nonsignificant in the cross ICSB $52 \times$ IS 13211 . The dominance component 
Table 5

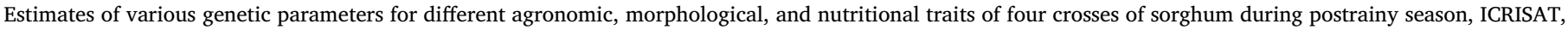
Patancheru, 2012-13.

\begin{tabular}{|c|c|c|c|c|c|c|c|}
\hline & Plant height $(\mathrm{cm})$ & Panicle length (cm) & Panicle width $(\mathrm{cm})$ & Grain yield/plant (g) & 100-grain weight (g) & Days to $50 \%$ flowering & Grain Fe $\left(\mathrm{mg} \mathrm{kg}^{-1}\right)$ \\
\hline \multicolumn{8}{|l|}{ ICSB $52 \times$ IS 13211} \\
\hline$\sigma^{2} g$ & 56.53 & 7.28 & 2.52 & 215.86 & 0.03 & 0.79 & 7.07 \\
\hline$\sigma^{2} a$ & 35.33 & 2.58 & -0.32 & 14.19 & 0.00 & 0.02 & 0.02 \\
\hline$\sigma^{2} \mathrm{~d}$ & 21.20 & 4.70 & 2.84 & 201.66 & 0.03 & 0.77 & 7.05 \\
\hline$\sigma^{2} p$ & 136.33 & 11.67 & 4.36 & 252.60 & 0.29 & 2.74 & 27.65 \\
\hline$h^{2} b$ & 0.42 & 0.62 & 0.58 & 0.86 & 0.10 & 0.29 & 0.26 \\
\hline$h^{2} n$ & 0.26 & 0.22 & -0.07 & 0.06 & 0.00 & 0.01 & 0.00 \\
\hline Degree of dominance & 3.94 & 7.67 & 1.49 & -2.84 & -2.01 & 1.30 & 2.38 \\
\hline
\end{tabular}

ICSB $52 \times$ SPV 1359

\begin{tabular}{|c|c|c|c|c|c|c|}
\hline & Days to flowering & Plant height $(\mathrm{cm})$ & Grain yield/plant (g) & 100-grain weight $(\mathrm{g})$ & Grain $\mathrm{Fe}\left(\mathrm{mg} \mathrm{kg}^{-1}\right)$ & Grain $\mathrm{Zn}\left(\mathrm{mg} \mathrm{kg}^{-1}\right)$ \\
\hline$\sigma^{2} g$ & 6.95 & 179.19 & -17.35 & 0.02 & 23.11 & 40.82 \\
\hline$\sigma^{2} \mathrm{a}$ & 0.53 & 19.24 & 3.69 & 0.01 & 2.20 & 0.23 \\
\hline$\sigma^{2} \mathrm{~d}$ & 6.42 & 159.96 & -21.04 & 0.01 & 20.92 & 40.59 \\
\hline$\sigma^{2} a$ & 9.47 & 230.28 & 43.14 & 0.19 & 36.42 & 53.64 \\
\hline$h^{2} b$ & 0.73 & 0.78 & 0.40 & 0.11 & 0.64 & 0.76 \\
\hline$h^{2} n$ & 0.06 & 0.08 & 0.09 & 0.04 & 0.06 & 0.00 \\
\hline Degree of dominance & 3.15 & -1.85 & -5.67 & -3.08 & 1.66 & -2.72 \\
\hline
\end{tabular}

IS $20843 \times$ IS 2248

\begin{tabular}{|c|c|c|c|c|c|c|c|}
\hline & Days to flowering & Plant height $(\mathrm{cm})$ & Panicle length $(\mathrm{cm})$ & Grain yield/plant $(\mathrm{g})$ & 100-grain weight (g) & Grain Fe $\left(\mathrm{mg} \mathrm{kg}^{-1}\right)$ & Grain Zn (mg kg $\left.{ }^{-1}\right)$ \\
\hline$\sigma^{2} g$ & 0.34 & 28.22 & 3.80 & 7.91 & 0.11 & 8.82 & 3.10 \\
\hline$\sigma^{2} \mathrm{a}$ & 0.09 & 1.24 & 0.39 & 0.26 & 0.00 & 2.31 & 2.83 \\
\hline$\sigma^{2} \mathrm{~d}$ & 0.25 & 26.98 & 3.41 & 7.65 & 0.12 & 6.52 & 0.27 \\
\hline$\sigma^{2} \mathrm{p}$ & 0.59 & 77.87 & 9.59 & 21.47 & 0.22 & 27.16 & 15.50 \\
\hline$h^{2} b$ & 0.58 & 0.36 & 0.40 & 0.37 & 0.52 & 0.33 & 0.20 \\
\hline$h^{2} n$ & 0.15 & 0.02 & 0.04 & 0.01 & -0.02 & 0.09 & 0.18 \\
\hline Degree of dominance & 1.69 & 10.78 & -0.93 & 2.08 & 3.00 & 0.64 & -1.53 \\
\hline
\end{tabular}

IS $2248 \times$ IS 20843

\begin{tabular}{|c|c|c|c|c|c|c|}
\hline & Days to flowering & Plant height $(\mathrm{cm})$ & Panicle width $(\mathrm{cm})$ & Grain yield/plant (g) & 100-grain weight (g) & Grain $\mathrm{Zn}\left(\mathrm{mg} \mathrm{kg}^{-1}\right)$ \\
\hline$\sigma^{2} g$ & 2.32 & 46.55 & 0.48 & 61.93 & 0.06 & 29.02 \\
\hline$\sigma^{2} \mathrm{a}$ & 1.12 & 29.05 & 0.08 & 32.13 & 0.03 & 3.91 \\
\hline$\sigma^{2} \mathrm{~d}$ & 1.20 & 17.49 & 0.40 & 29.80 & 0.04 & 25.11 \\
\hline$\sigma^{2} p$ & 3.08 & 112.10 & 2.02 & 78.25 & 0.20 & 49.89 \\
\hline$h^{2} b$ & 0.75 & 0.42 & 0.24 & 0.79 & 0.32 & 0.58 \\
\hline$h^{2} n$ & 0.36 & 0.26 & 0.04 & 0.41 & 0.14 & 0.08 \\
\hline Degree of dominance & -0.96 & 2.37 & -2.76 & -1.85 & -1.16 & 0.88 \\
\hline
\end{tabular}

$\sigma^{2} \mathrm{~g}=$ genotypic variance; $\sigma^{2} \mathrm{a}=$ additive variance; $\sigma^{2} \mathrm{~d}=$ dominance; $\sigma^{2} \mathrm{p}=$ phenotypic variance; $\mathrm{h}^{2} \mathrm{~b}=$ broad-sense heritability; and $\mathrm{h}^{2} \mathrm{n}$, narrow-sense heritability.

was found significant in a positive direction in all the crosses except IS $2248 \times$ IS 20843, wherein a non-significant gene action was observed for this trait. Among the interactions, the additive $\times$ additive component was found significant in a positive direction in the crosses ICSB $52 \times$ IS 13211 and IS $20843 \times$ IS 2248 and non-significant in the crosses ICSB $52 \times$ SPV 1359 and IS $2248 \times$ IS 20843. The dominance $\times$ dominance interaction was significant in a negative direction only in the cross IS $20843 \times$ IS 2248 , and non-significant in the remaining crosses. Like in all the traits, additive $\times$ dominance interaction was found non-significant for the trait in all the crosses.

For grain zinc concentration, the additive component was significant in all the crosses except ICSB $52 \times$ IS 13211, whereas dominance and additive $\times$ additive components of epistasis were positively significant in the crosses ICSB $52 \times$ IS 13211 and IS $20843 \times$ IS 2248 . The dominance $\times$ dominance component was significant in a negative direction for the cross IS $20843 \times$ IS 2248 . Thus, the additive component was playing a significant role in governing grain zinc concentration. This suggests that early generation selections and selecting parents with high grain zinc concentration can be adopted to exploit the additive component of gene action which may result in improved varieties and hybrids with high grain zinc concentration.

\section{Discussion}

Understanding inheritance pattern, heritability and gene action greatly help in enhancing grain Fe and $\mathrm{Zn}$. Generation mean analysis provides information on the relative importance of average effects of the genes (additive effects), dominance deviations, and effects due to non-allelic genic interactions, in determining genotypic values of the individuals and, consequently, mean genotypic values of families and generations. This study showed that the mean sums of squares due to generations were significant, indicting the presence of genetic diversity in the material used for the study. For grain Fe concentration, the dominance component of variance was higher than the additive component in all the crosses while non-allelic interactions had a greater role in influencing the trait. Similar results were reported by Chakraborti et al. (2010) in Maize. For grain Zn, the additive component played a significant role in governing the trait while large interaction effects were also observed. Additive gene action in the inheritance of grain iron and zinc concentrations in pearl millet through combining ability analysis was reported earlier (Velu et al., 2011 and Govindraj et al., 2013). The mean performance of the parents and the progenies showed that in order to improve both the grain $\mathrm{Fe}$ and $\mathrm{Zn}$ concentrations simultaneously, both parents should be improved for Fe and $\mathrm{Zn}$, and in 
case only Fe is targeted, at least one of the parents should contain high amounts of Fe. The generation mean studies indicated the presence of gene interactions in the inheritance of all the agronomic traits studied. Days to flowering, plant height, grain yield, 100-grain weight and grain $\mathrm{Zn}$ concentration showed epistatic interactions in their inheritance with a high degree of dominance and dominance variance indicating the predominance of dominance gene action. Similar results have been reported in sorghum (Mohammed et al., 2018). Panicle length, panicle width, and grain Fe concentration showed additive dominance interactions with a high degree of dominance and dominance variance indicating the predominance of dominance gene action earlier in sorghum (Narain et al., 2007; Rani et al., 2008; Yongfu Tao et al., 2017).

\section{Conclusion}

The estimate of generation mean parameters in sorghum indicated that there was significant influence of all three types of gene actions, additive, dominance and epistasis gene components in the expression of grain iron and zinc concentrations. This means that superior lines with higher mineral concentrations can be developed by applying effective selection using reciprocal recurrent strategies. The presence of non-allelic interactions and predominance of dominant gene action for the $\mathrm{Fe}$ and $\mathrm{Zn}$ traits indicated that heterosis breeding can be used in developing high iron and zinc hybrids. If grain $\mathrm{Zn}$ alone is the target, selection in the early generations for line development followed by using both parents improved for $\mathrm{Zn}$ will give improved hybrids. Since several important characters are influenced by dominance and non-allelic gene interaction, it is advisable to delay selection to later generations which increase the homozygosity. The results of this study will help in identifying appropriate parents, in selecting promising plants form segregating generations, and in developing sorghum cultivars with high Fe and $\mathrm{Zn}$ concentrations possessing higher grain yield. This is a first report on using generation mean analysis to study inheritance of grain $\mathrm{Fe}$ and $\mathrm{Zn}$ concentrations in sorghum.

\section{Acknowledgments}

The authors wish to thank the sorghum breeding staff for their help in conducting field trials in this work which was supported by the HarvestPlus CGIAR Challenge Program Grant No 5321. First author Anil Gaddameedi is grateful to the University Grants Commission (UGC) - Rajiv Gandhi National Fellowship, Government of India, for the fellowship provided during the course of this work.

\section{References}

Arzani, A., Ashraf, M., 2017. Cultivated ancient wheats (Triticum spp.): a potential source of health beneficial food products. Compr. Rev. Food Sci. Food Saf. 16 (3), 477-488. Arzani, A., Zeinali, H., Razmjo, K., 2007. Iron and magnesium concentrations of mint accessions (Mentha spp.). Plant Physiol. Biochem. (Paris) 45 (5), 323-329.

Ashok Kumar, A., Reddy, B.V.S., Ramaiah, B., Reddy, P.S., Sahrawat, K.L., Upadhyaya, H.D., 2009. Genetic variability and plant character association of grain Fe and $\mathrm{Zn}$ in selected core collection accessions of sorghum germplasm and breeding lines. J. SAT Agric. Res. 7, 1-4.

Ashok Kumar, A., Reddy, B.V.S., Rai, K.N., 2011. Genetic variability for grain Fe and Zn concentrations in sorghum and pearl millet cultivars. Souvenir of the Ind. Seed Cong. 95-99.

Ashok Kumar, A., Reddy, B.V., Ramaiah, B., Sahrawat, K.L., Pfeiffer, W.H., 2012. Genetic variability and character association for grain iron and zinc concentrations in sorghum germplasm accessions and commercial cultivars. Eur. J. Plant Sci. Biotechnol. 6 (1), 1-5.

Ashok Kumar, A., Reddy, V.S.B., Ramaiah, B., Sahrawat, K.L., Pfeiffer, W.H., 2013. Gene effects and heterosis for grain iron and zinc concentration in sorghum [Sorghum bicolor (L.) Moench]. Field Crop. Res. 146, 86-95.

Bailey, R.L., West Jr., K.P., Black, R.E., 2015. The epidemiology of global micronutrient deficiencies. Ann. Nutr. Metab. 66 (Suppl. 2), 22-33.

Bavei, V., Shiran, B., Arzani, A., 2011. Evaluation of salinity tolerance in sorghum (Sorghum bicolor L.) using ion accumulation, proline and peroxidase criteria. Plant Growth Regul. 64 (3), 275-285.

Bouis, H.E., Welch, R.M., 2010. Biofortification - a sustainable agricultural strategy for reducing micronutrient malnutrition in the global south. Crop Sci. 50 (Suppl. 1), S-20.

Cavalli, L.L., 1952. An analysis of linkage in quantitative inheritance. In: Rieve, E.C.E., Waddingon, C.H. (Eds.), Quant. Inher. HMSO, London, pp. 144.

Chakraborti, M., Prasanna, B.M., Anju, M.S., Hossain, F., 2010. Generation mean analysis of kernel iron and zinc concentrations in maize (Zea mays). Indian J. Agric. Sci. 80 (11), 956-959.

FAO STAT, 2016. http://www.fao.org/faostat/en/\#data/QCGovindaraj, M., Rai, K.N. Shanmugasundaram, P., Dwivedi, S.L., Sharawat, K.L., Muthaiah, A.R and Rao, A.S 2013. Combining ability and heterosis for grain iron and zinc densities in pearl millet. Crop Sci. 53 :507-517.

Indosat software services, 2004. Windostat. Indosat services. http://www.indostat.org.

Ma, G., Jin, Y., Li, Y., Zhai, F., Kok, F.J., Jacobsen, E., Yang, X., 2008. Iron and zinc deficiencies in China: what is a feasible and cost-effective strategy. Publ. Health Nutr. 11 (6), 6326378.

Mather, K., 1949. Biometrical Genetics: the Study of Continuous Variation. Methuen and Co. Ltd., London.

Mather, K., Jinks, J.L., 1971. Components of means: additive and dominance effects. In: Biometrical Genet, pp. 65-82.

Mohammed, Riyazaddin, Ashok Kumar, A., Munghate, R.S., Gaddameedi, A., Kavi Kishor, P.B., Sharma, H.C., 2018. Pattern of genetic inheritance of morphological and agronomic traits of sorghum associated with resistance to sorghum shoot fly, Atherigona soccata. Euphytica (TSI) 214 (2), 1-20 32.

Nahla, et al., 2017. The prevalence of micronutrient deficiencies and inadequacies in the Middle East and approaches to interventions. Nutrition 9 (3), 229.

Narain, V., Singh, P.K., Kumar, N., Singh, V.S., 2007. Gene effects for grain yield and related traits in sorghum (Sorghum bicolor L. Moench). Indian J. Genet. Plant Breed. 67 (1), 34-36.

Nestel, P., Bouis, H.E., Meenakshi, J.V., Pfeiffer, W., 2006. Biofortification of staple food crops. J. Nutr. 136, 1064-1067.

Parthasarathy Rao, P., Birthal, B.S., Reddy, B.V.S., Rai, K.N., Ramesh, S., 2006. Diagnostics of sorghum and pearlmillet grains-based nutrition in India. Int. Sorghum Millets Newsl. 47, 93-96.

Phuke, R.M., Anuradha, K., Radhika, K., Jabeen, F., Anuradha, G., Ramesh, T., Kumar, A.A., 2017. Genetic variability, genotype $\times$ environment interaction, correlation, and GGE biplot analysis for grain iron and zinc concentration and other agronomic traits in RIL population of sorghum (Sorghum bicolor L. Moench). Front. Plant Sci. 8, 712

Rani, K.J., Rao, S.S., Ganesh, M., 2008. Gene effects for grain yield and panicle components in rabi sorghum (Sorghum bicolor (L.) Moench). J. Res ANGRAU. 36 (2\&3), $44-48$.

Reddy, B.V.S., Ramesh, S., Longvah, T., 2005. Prospects of breeding for micronutrients and P-carotene-dense sorghums. J. SAT Agric. Res. 1 (1), 1-4.

Tao, Yongfu, Mace, Emma S., Tai, Shuaishuai, Cruickshank, Alan, Campbell, Bradley C., Zhao, Xianrong, VanOosterom, Erik J., Godwin, Ian D., Botella, Jose R., Jordan, David R., 2017. Whole-genome analysis of candidate genes associated with seed size and weight in Sorghum bicolor reveals signatures of artificial selection and insights into parallel domestication in cereal crops. Front. Plant Sci. 8, 1237.

Velu, G., Rai, K.N., Muralidharan, V., Longvah, T., Crossa, J., 2011. Gene effects and heterosis for grain iron and zinc density in pearl millet (Pennisetum glaucum (L.) R. Br). Euphytica 180 (2), 251-259.

Wheal, M.S., Fowles, T.O., Palmer, L.T., 2011. A cost-effective acid digestion method using closed polypropylene tubes for inductively coupled plasma optical emission spectrometry (ICP-OES) analysis of plant essential elements. Anal. Methods. 3, $2854-2863$.

White, P.J., Broadley, M.R., 2006. Biofortifying crops with essential mineral elements Trends Plant Sci. 10 (12), 586-593.

Pfeiffer, W.H., McClafferty, B., 2007. HarvestPlus: breeding crops for better nutrition. Crop Sci. 47 (Suppl. ment_3), S-88.

Zhao, F.J., McGrath, S.P., 2009. Biofortification and phytoremediation. Curr. Opin. Plant Biol. 12, 373-380. 